\title{
Natural Polymers for Body Care to Save the Environment
}

\author{
Pierfrancesco Morganti ${ }^{1 *}$, Tommaso Anniboletti ${ }^{2 *}$, Pollastrini $\mathrm{C}^{3}$ and G Morganti ${ }^{4}$ \\ ${ }^{1}$ L Vanvitelli, Dermatol Unit, Italy \\ ${ }^{2}$ Burn Centre and Plastic Surgery Department, S Eugenio Hospital, Italy \\ ${ }^{3}$ Nurse, Wound Care Specialist, S Eugenio Hospital, Italy \\ ${ }^{4}$ ISCD Nanoscience Center, Italy \\ *Corresponding author: Pierfrancesco Morganti, L Vanvitelli, Dermatol Unit, Naples, Italy and Tommaso Anniboletti, Burn Centre \\ and Plastic Surgery Department, S Eugenio Hospital, Rome, Italy
}

\begin{tabular}{|c|c|}
\hline ARTICLE INFO & ABSTRACT \\
\hline Received: 㓞 April 10, 2019 & Citation: Pierfrancesco M, Tommaso A, Pollastrini C, G M. Natural Polymers for Body Care \\
\hline Published: 㓞 April 17, 2019 & Save the Environment. Biomed J Sci \& Tech Res 17(1)-2019. BJSTR. MS.ID.002955. \\
\hline
\end{tabular}

\section{Introduction}

Due to the increasing waste material that is creating environmental pollution with a continuous increase of greenhouse gas (GHG) emissions and great disasters in our Planet, it is necessary to change our way of living and thinking to save the environment and human health. Unfortunately, our society uses and consumes high quantity of plastic materials that, with the high quantity of food lost during the production, distribution and consume chain, contributes to produce the majority of waste and

$\mathrm{CO}_{2}$ invading the Planet (Figure 1a/b) [1-3]. Plastic raw material,is used to produce among others different kind of goods, such as soft and hard packagings, cosmetic and medical products and tools, used for surgery purposes also. These products are made by the use of polymers petrol-derived that unfortunately are not biodegradable and remain as waste in the land and oceans for hundred of years as different items (Figure 2) creating great problems to both flora and fauna $[3,4]$.

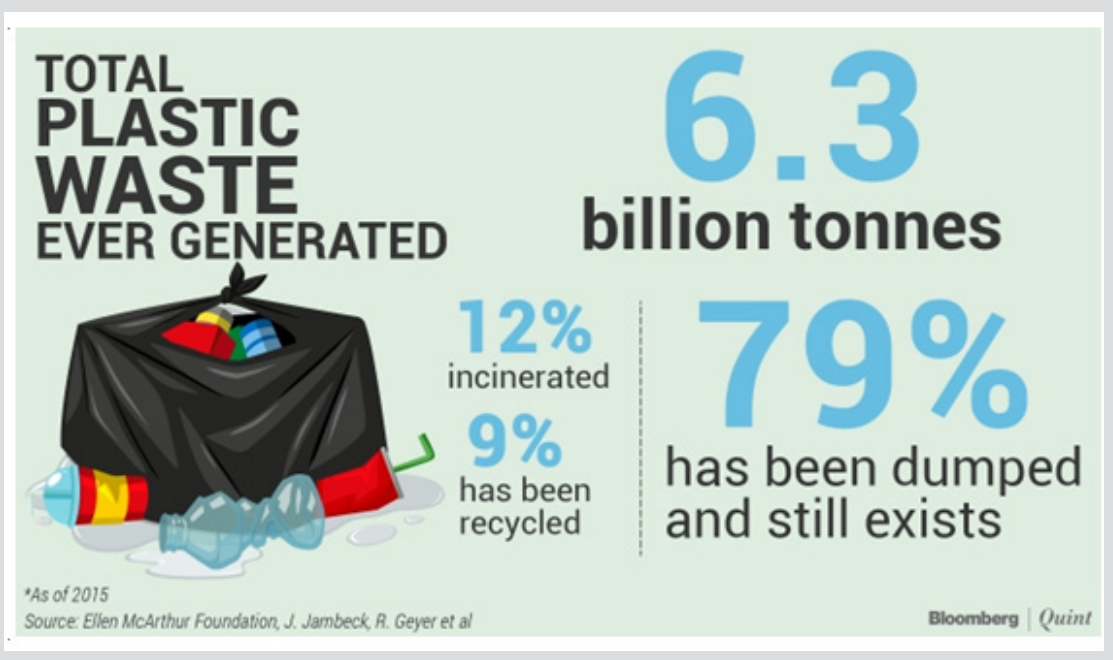

Figure 1: Plastic waste( on top )and Food losses worldwide(below). 


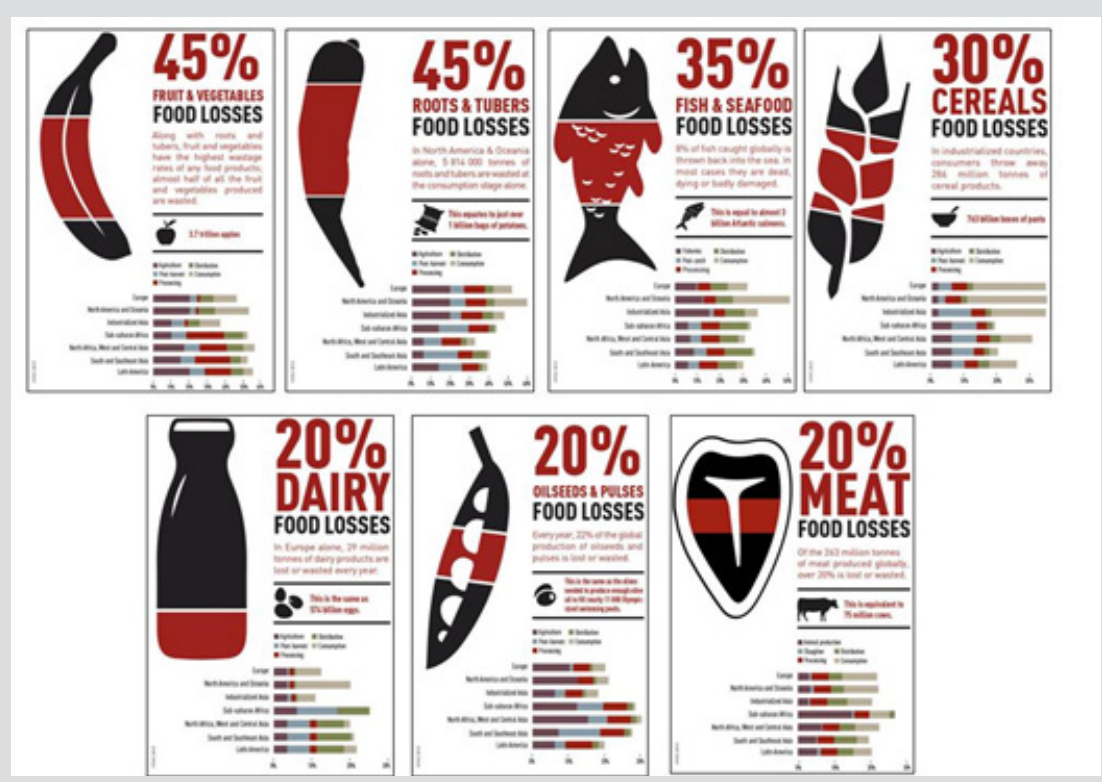

Figure 2: Plastic items remaining into the land and ocean for hundreds of years.

The Alternative Solution

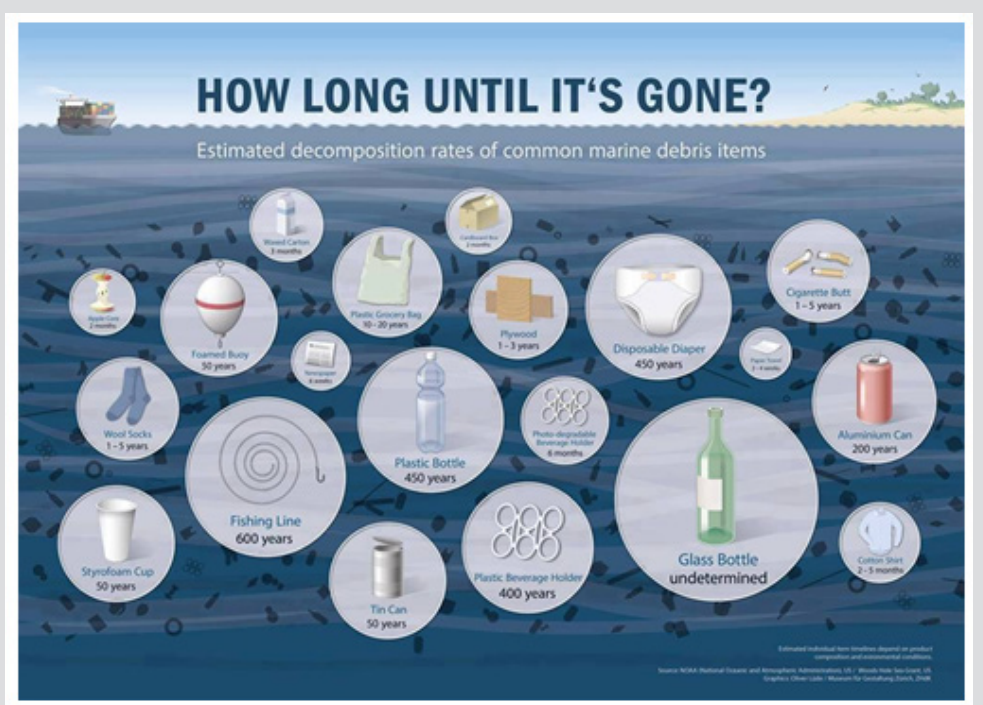

Figure 3: Photo at SEM of chitin nanofibril network (CN)(left) compared to natural Extra cellular matrix(ECM) (right).

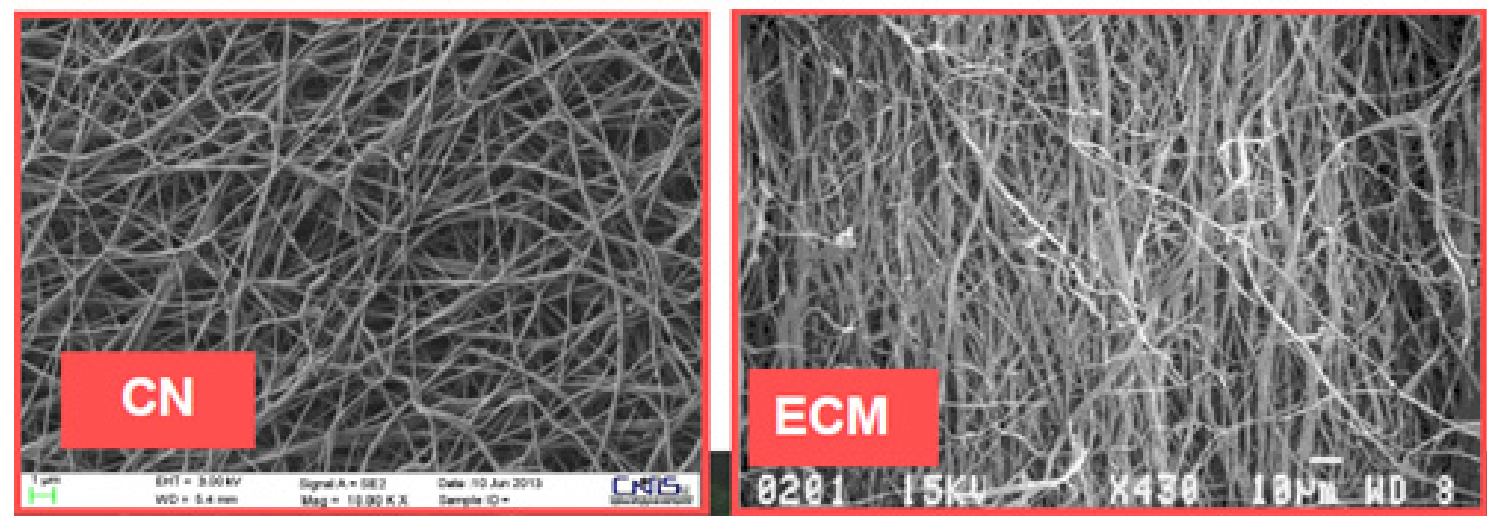

Figure 4: Deep 2nd degree burn of a left forearm caused by hot water in a 67 years-old man(a). 
Thus, the necessity to research alternative solutions by the use of natural bio-based polymers (i.e. the so called biopolymers) which, obtained from waste materials, may be used to make biodegradable non-woven tissues, skin-friendly and environmentally-friendly. Our group, working from many years on this sector of research, has published many papers showing the possibility to produce nonwoven tissues and films, characterized for having antiiflammatory, immunomodulating and antibacterial effectiveness [5-7].These tissues, made by natural nanostructured polymers such as chitin nanofibrils (CN)and biolignin (LG),have been developed as matrices that mimic the key characteristics of the Extracellular matrix (ECM) (Figure 3) [8].They, in fact, seem to have the ability to transmit the biochemical signals necessary to sequester , prevent and orient the many morphoregulatory molecules able to control cell division, differentiation and growth. Thus, a tissue ECM-like (Figure 3), based on the complex CN-LG was applied as a dressing for superficial and deep second degree burns on a 67 years-old man with injury on the left forearm. This innovative tissue has solved an important role on skin regeneration with results comparable to other dressing commonly used and a shorter healing time,modulating the bacteria growth also (Figure 4)[9].

\section{Role of Chitin-Lignin Nanostructured}

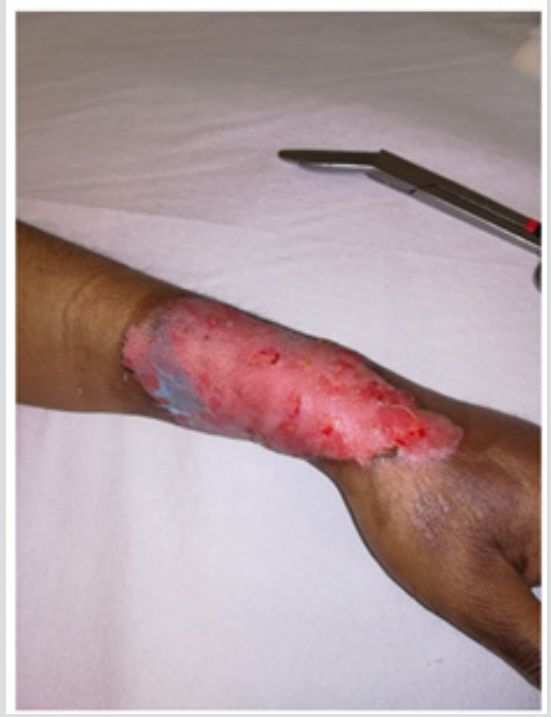

Figure 5a: Before treatment.

It is interesting to underline that while chitin nano-fibril is an electropositive polymer, bio-lignin has composed by nanoparticles with a surface covered by electronegative charges. Thus,it has been possible to make nano-chitin/nano-lignin complexes by the simple gelation technology (Figure 5a).These complexes, able to encapsulate different active ingredients, have been embedded into emulsions or bound to polysaccharide-non woven tissues to be used as sheets for baby diapers, face beauty masks and advanced medications, according also to the in progress EU polybioskin research project(www.polybioskin.eu) [10-13] (Figure 5b). Regarding the interesting actives shown by the chitin-lignin ( CN-LG) micro/nanoparticles as drug and cosmetic carrier, it is to remember it's own peculiarity (Figure 5c). On the one hand, it is able to load and carry the active ingredients to the designed skin location, releasing them at the desired dose and programmed time.
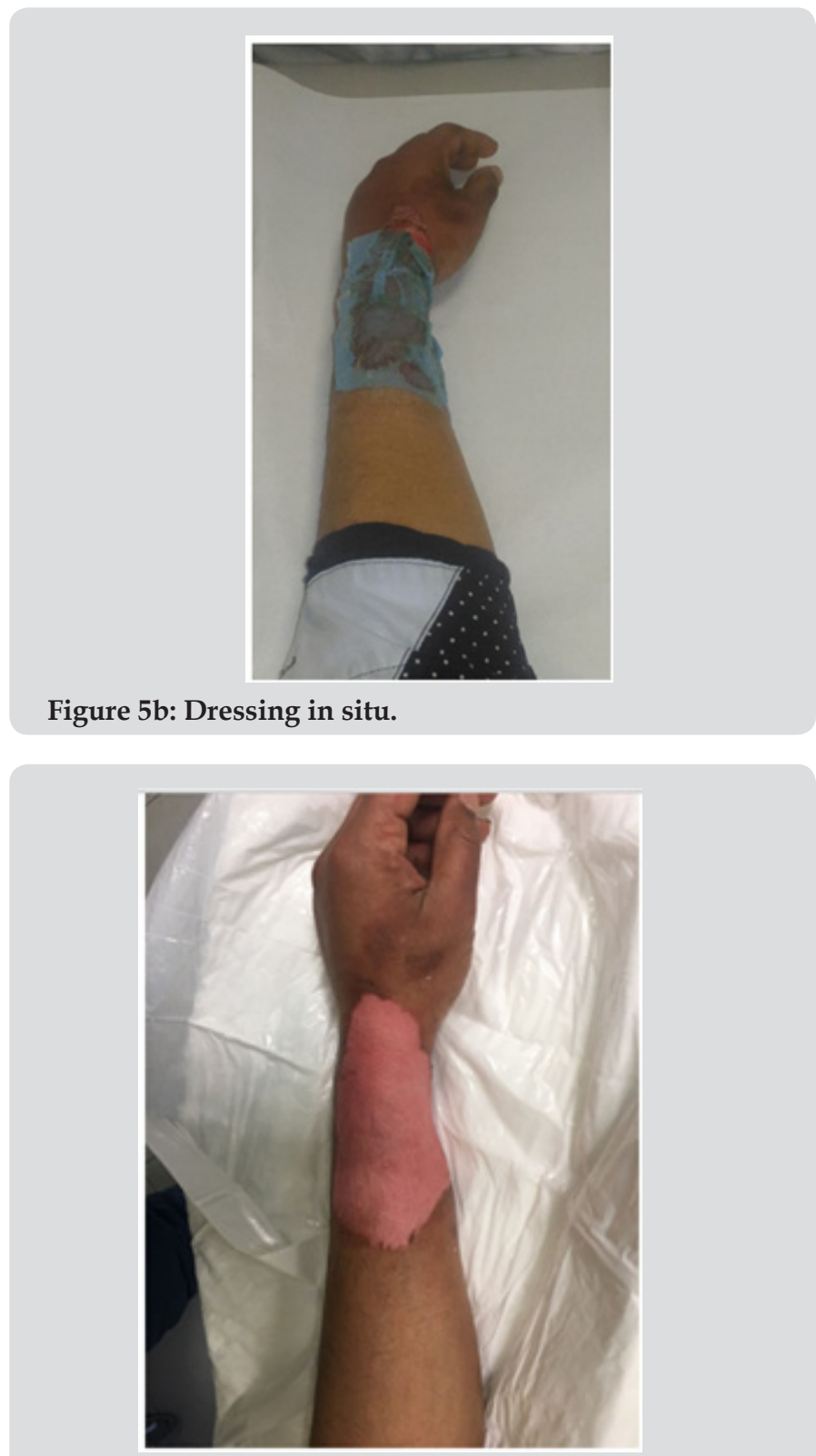

Figure 5c: result after 2 weeks of treatment. It is possible to see that the skin is completely regenerated with a good. aesthetic result.

On the other hand, it acts as a smart "active" carrier (Figure 6) being composed in part from chitin nanofibrils ,easily metabolized in glucosamine, acetyl glucosamine, and glucose used from the cells to make glycosaminoglycans and/or more complex macromolecules or as energy respectively; on the other part nano-lignin is used as an antioxidant and photoprotective ingredient because rich in polyphenol molecules [14] (Figure 7). Both chitin and lignin are, therefore, easily biodegraded by the human and environment' enzymes, without producing toxic compounds. On the contrary both chitin and lignin, if not processed properly ,may have a negative impact on human health, biodiversity and environments. 


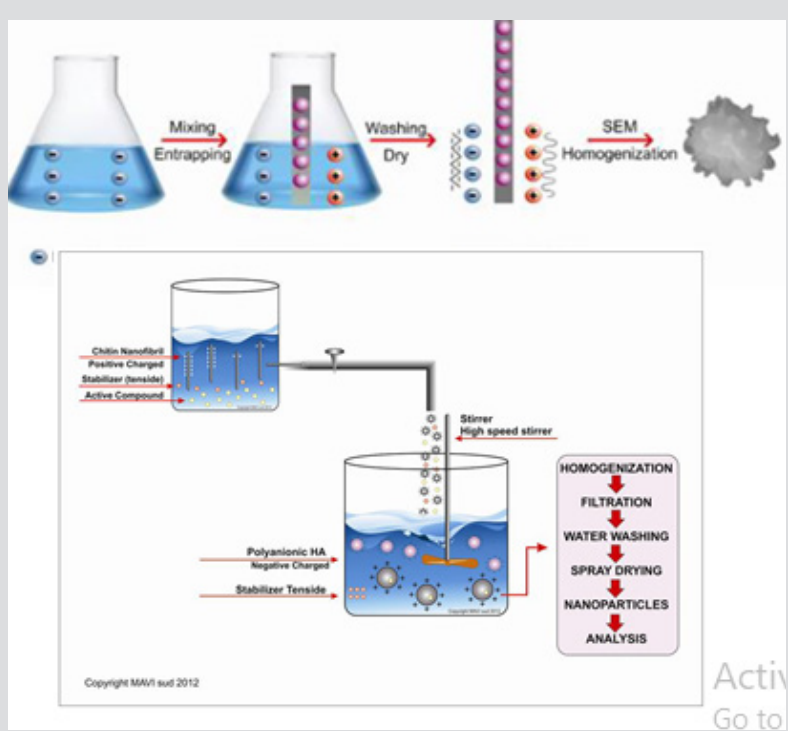

Figure 6: Gelation method to make chitin Nanofibril-Nanolignin or Hyaluronic aci (HA) complexes entrapping active ingredients.

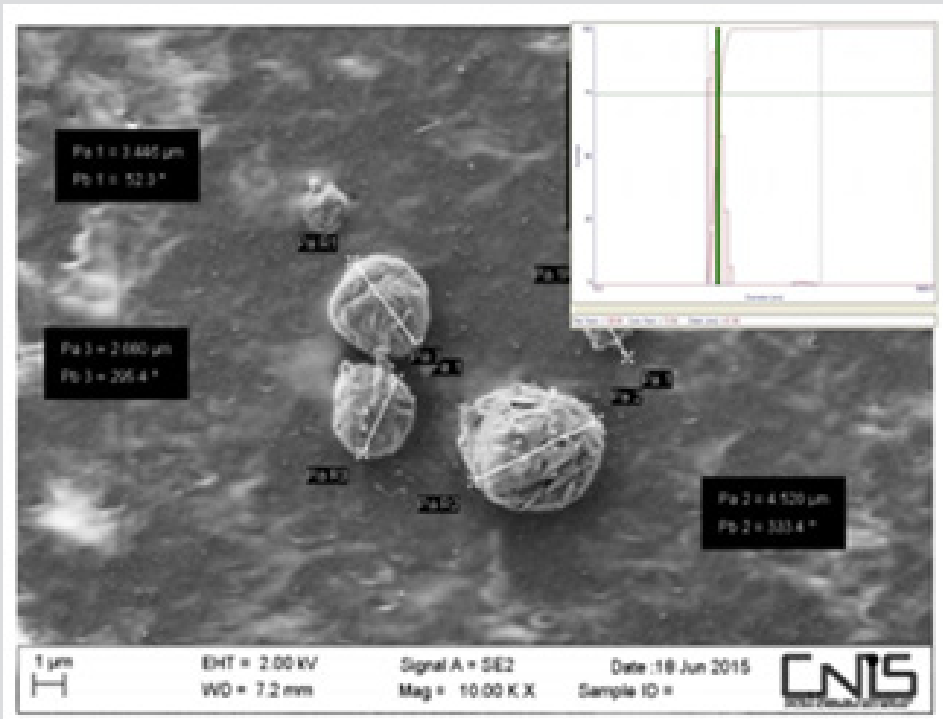

Figure 7: Chitin Nanofibrils-nanolignin biodegradable and smart carrier at SEM.

\section{Conclusive Remarks}

In conclusion, chitin nanofibrils and biolignin, which represent each year a global waste material of about 300 billion of tonnes, produced respectively as underutilized by-product of fishery's industry and agricultural biomass, could be used in the medical field also to make innovative and eco-compatible products and tools. The major utilization of this waste may be useful to preserve the natural raw materials for the incoming generations, contemporary reducing the GHG emissions necessary to save our Planet and its biodiversity.

\section{References}

1. FAO (2011) Global Food Losses and Food Waste. Extent,Causes and prevention.

2. Royer SJ, Ferron S, Wilson ST, Karl DM (2018) Production of methane and ethylene from plastic in the environment.PLoS ONE 13(8): e0200574.
3. Jambeck JR, Geyer R, Wilcox C, Siegler TR, Perryman M, et al. (2015) Plastic waste inputs from and into the ocean. Science 347: 767-77.

4. Priestland E, Sherrington C, Darrah C, Winter J, Watson S (2017) Plastics and the Marine Environment. SEAS AT RISK Ed. Brussels Belgium 9:205229.

5. Morganti P, Del Ciotto P, Stoller M, Chianese A (2016) Antibacterial and Anti-inflammatory Green Nanocomposites. Chem Eng Transactions 47:61-66.

6. Morganti P, Fusco A, Paoletti I, Perfetto B, Del Ciotto P, et al. (2017) Anti-inflammatory ,immunomodulatory and Tissue Repair Actuvity on Human Keratinocytes by Green Innovative Nanocomposites. Materials 10(7): 843 .

7. Morganti P (2019) Bionanotechnology to Save the Environment. Plant and Fishery's Biomass as Alternative to Petrol. MDPI, Basel, Switzerland.

8. Morganti P, Febo P, Cardillo M, Donarumma G, Baroni A (2017) Chitin Nanofibril and Nanolignin: Natural polymers of biomedical Interest. J Clin Cosmet Dermatol 1: 1-7. 
9. Anniboletti T, Palombo M, Moroni S, Bruno A, Palombo P, et al (2019) Clinical Activity of Non-Woven Tissues. In: P. Morganti (Eds.), Bio nanotechnology to Save the Environment MDPI Edition, Basel, Switzerland pp. 340-36.

10. Morganti P, Coltelli MB, Danti S, Bugnicourt E (2017) The skin goal of EU Polybioskin project. Global Res J Pharm Pharmacol 2(1): 7-13.

11. Morganti P, Coltelli MB, Morganti G (2018) Natural Polymers for a cleaner Environment. Int J Nanotechnol Nanomedicine 3(1): 1-4.

\section{ISSN: 2574-1241}

DOI: 10.26717/BJSTR.2019.17.002955

Pierfrancesco Morganti. Biomed J Sci \& Tech Res

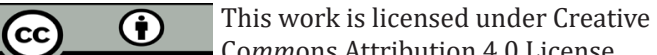

Submission Link: https://biomedres.us/submit-manuscript.php
12. Morganti P, Danti S, Coltelli MB (2018) Chitin and Lignin to produce Biocompatible tissues. Res Clin Dermatol 1(1): 5-11.

13. Morganti P, Febo P (2018) Innovative tissue engineering for enlarget market. J Clin Cosmet Dermatol 1(4): 21.

14. Morganti P, Palombo M, Carezzi F, Nunziata ML, Morganti G, et al. (2016) Green Nanotechnology Serving the Bioeconomy: Natural Beauty Masks to save the Environment. Cosmetics 3: 41.

$\begin{array}{ll}\text { BIOMEDICAL } & \text { Assets of Publishing with us } \\ \text { RESEARCHES } & \text { - Global archiving of articles } \\ & \text { - Immediate, unrestricted online access } \\ \end{array}$

